\title{
Enhancing the Properties of Marl Soils for Effective Construction in Saudi Arabian Region
}

\author{
Md. Arifuzzaman ${ }^{1, *}$, Muath Najjar ${ }^{2}$, Mahmud Naser Mahmud $^{2}$, A. B. M. Saiful Islam ${ }^{3}$, \\ Imran $\mathrm{Khan}^{4}$, and M. M. Ali ${ }^{5}$
}

\author{
1 Department of Civil Engineering, University of Bahrain, Bahrain \\ 2 Department of Civil Engineering, King Fahd University of Petroleum and Minerals, Saudi Arabia \\ 3 Department of Construction Engineering, University of Dammam, Saudi Arabia \\ 4 Department of Civil Engineering, King Faisal University, Saudi Arabia \\ 5 California Public Utilities Commission, California 95834, USA \\ *E-mail: arafiquzzaman@uob.edu.bh (Corresponding author)
}

\begin{abstract}
Marl, containing primarily carbonate $\left(\mathrm{CaCO}_{3}\right)$ and clays of different percentages with occasional traces of organic matter, silt or sand is usually used as bases and sub-bases for roads and highways. Marl is usually used as sub-grade layers or as a backfill in base and sub-base layers for highway pavements. This type of soil has poor strength and high water sensitivity; a drastic loss of bearing capacity may occur upon immersion. Due to its poor strength and high water sensitivity, appropriate treatment from engineering perspective is necessary before such soils are recommended for use in any construction project effectively. Critical analysis of different stabilization techniques employed for enhancing the marl soil properties in Saudi Arabia for the last 30 years has been carried out to find the best engineering solution. Mechanical and chemical treatments were found to be more economical than drainage, dewatering and other techniques. It has been noticed that no study was done in stabilization of Marl Soil using Geo-synthetics technique Hence, it can be an alternate way for future research to improve marl.
\end{abstract}

Keywords: Marl, improvement, stabilization, strength, durability, chemical agent.

ENGINEERING JOURNAL Volume 21 Issue 4

Received 13 December 2016

Accepted 5 February 2017

Published 31 July 2017

Online at http://www.engj.org/

DOI:10.4186/ej.2017.21.4.111 


\section{Introduction}

Saudi Arabia is experiencing a huge monetary quantity spending in construction industry for the last few decades. But, the land area is situated on some kind of problematic type of soils such as Sabkha, Marls etc. Sabkha soil was investigated by many researchers [1] but the detailed informative investigation for marl soil in literature are not quite common from informative and data base view point.

The word "marl" frequently used to describe and represent all the different types of calcareous and associated materials (containing, or partly composed of calcium carbonate $(\mathrm{CaCO} 3)$ and clay in different percentages existent in the Saudi Arabian Eastern Province [2]. As a primarily calcareous material, the marl is affected by composition of minerals, type of present carbonate mineral, origin and its formation process, degree of cementation and grain-size distribution [2]. The formation of marl soil is thought to be a result of physical as well as chemical weathering of original carbonate rock. In most of the cases, marl is existed as consolidated or, rather cemented layer of carbonate deposits. Additional definitions and attributes used by different authors are shown in Table 1.

In Eastern Saudi Arabia (as shown in Fig. 1.), marl, is one of the common soils being used extensively as foundation materials for pavements and other structures. Its characteristics vary greatly from place to place depending on color and plasticity as well as chemical and physical composition. The engineering properties of the calcareous soil are influenced by several factors such as: carbonate content, particle size, degree of indurations, and origin of carbonate material, environmental conditions and construction procedures. The variation in unit weight (or density) and percentage of moisture content, and also the post depositional changes affect the behavior of the marl soil [2]. This can be due to mainly the presence of different type of impurities: gypsum, calcite, aragonite, dolomite, quartz, sand, geodes, etc. Moreover, the properties of this soil are observed to be time dependent due to their extensive layering [3]. Aiban [3] conducted laboratory compression and strength tests on Abqaiq Marl. High quantity of calcite and dolomite were observed in Abqaiq marls. It was also observed that the engineering properties were highly affected by moister content.

Marl, being a marginal and water sensitive soil, cannot be utilized as a construction material in its natural state, as many highway pavement failures have been observed. Due to their water sensitivity and low strength, there have been attempts to improve by stabilize the engineering properties of calcareous type of material content soils using additives like: cement, cut-back asphalt, emulsified asphalt and lime. Most of the chemical treatments resulted in various degrees of success. The stabilized marl soils were recommended to use in bases, sub-bases, building foundations and other construction applications, even when the water could reach into these soils. Nonetheless, marl seems to be the best option as foundation material in Eastern Saudi Arabia since the unviability of other high quality soil.

Recent Studies [4-7]) on soil treatments showed that additives, such as lime for clayey and cement for sandy soils were used to enhance strength, reduce volume changes and consequently stabilize the soil. However a viable soil stabilization technique is of great interest to all involved in the development. Therefore, the study aims to identify a competent technique for stabilization of Marl soil. Critical assessment has been done among different stabilization techniques conducted in last 30 years within Saudi Arabia. The viability of the approaches has been explored together with their shortcomings. The best technique has then been recommended to be used for stabilization of Marl Soil in Saudi region. 


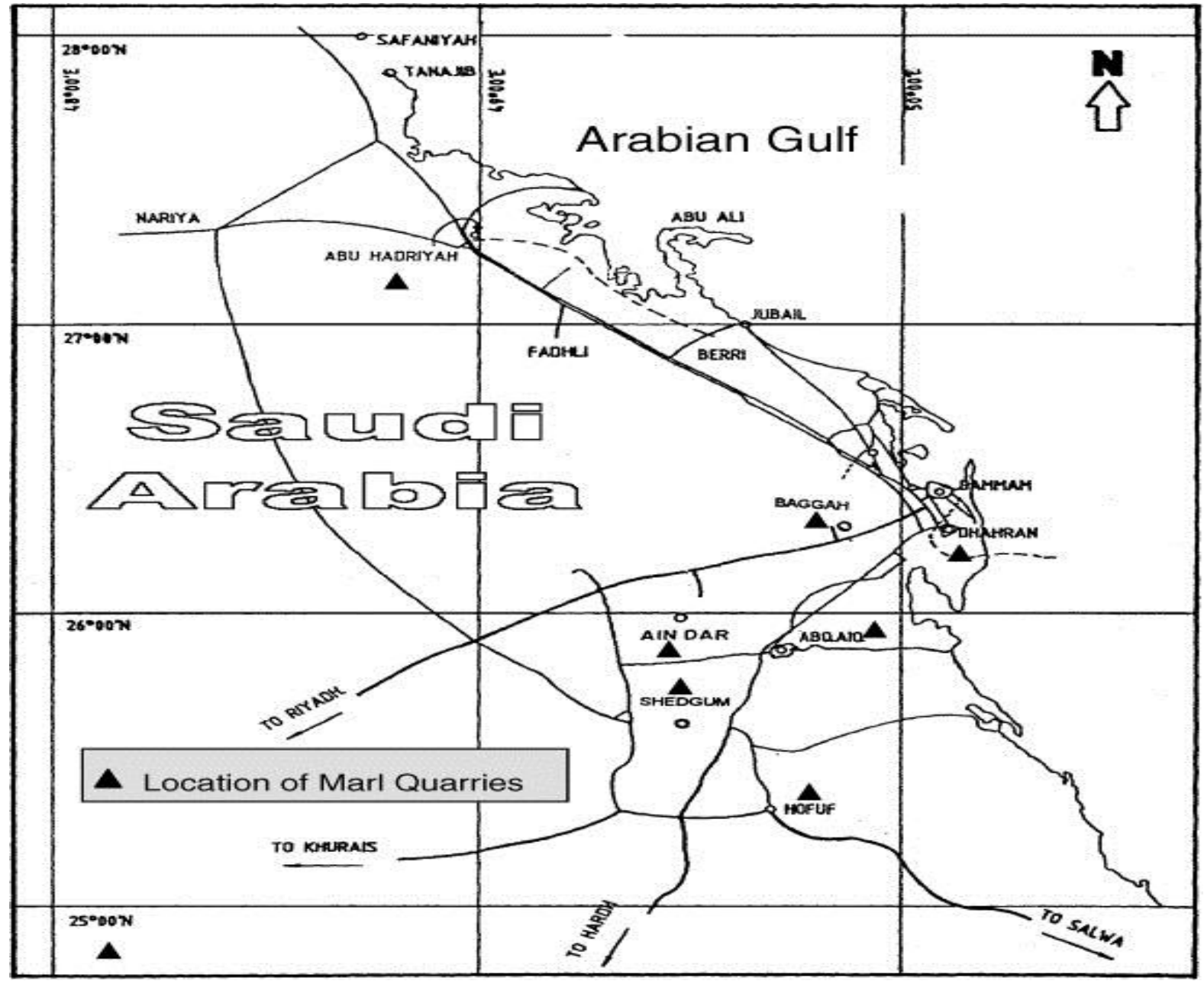

Fig. 1. Map locations for major Marl quarries in Saudi Arabian eastern part [8].

Table 1. Marl soil definitions and attributes used in different studies [9].

\begin{tabular}{|c|c|c|}
\hline Author(s) & Year & Definitions and attributes \\
\hline $\begin{array}{l}\text { Terzaghi } \\
\text { and Peck }\end{array}$ & 1967 & A marine and calcareous clays with stiff to very stiff nature with greenish color \\
\hline Petti john & 1975 & $\begin{array}{l}\text { Rock or soil type material containing } 35-65 \% \text { carbonate with a complementary } \\
\text { clay percentage }\end{array}$ \\
\hline $\begin{array}{l}\text { Fookes, } \\
\text { Higgin } \\
\text { bottom }\end{array}$ & 1975 & A simple and binary mixture of calcium carbonate and clay \\
\hline McCarthy & 1977 & Soft type of limestone \\
\hline Challinor & 1978 & $\begin{array}{l}\text { A mixture of rocks which contain clay minerals, aragonite and calcite, such as } \\
\text { silt, but in minimum quantity }\end{array}$ \\
\hline $\begin{array}{l}\text { Saudi- } \\
\text { ARAMCO }\end{array}$ & 1978 & Soft limestone which is contaminated with varying percentages of clay \\
\hline $\begin{array}{l}\text { Sowers } \\
\text { and } \\
\text { Sowers }\end{array}$ & 1979 & Sand, silt and clay type of calcium carbonate which are deposited by water \\
\hline $\begin{array}{l}\text { Bates and } \\
\text { Jackson }\end{array}$ & 1980 & $\begin{array}{l}\text { Marl is an old form of soil which is generally and loosely applicable to a long } \\
\text { ranges of materials, mostly consisted of an close mixture of clay and calcium }\end{array}$ \\
\hline
\end{tabular}




\begin{tabular}{|l|l|l|} 
& & carbonate \\
\hline $\begin{array}{l}\text { Mitchell, } \\
\text { R.S. }\end{array}$ & 1985 & Soft calcareous and clay based mineral \\
\hline $\begin{array}{l}\text { Blyth and } \\
\text { de Freitas }\end{array}$ & 1985 & Mudstone which are calcareous nature \\
\hline $\begin{array}{l}\text { Al-Tayyib } \\
\text { et al. }\end{array}$ & 1985 & $\begin{array}{l}\text { Carbonated type soils, the formation attributed by physical as well as } \\
\text { weathering (chemical) of the parent carbonate and associated rocks }\end{array}$ \\
\hline $\begin{array}{l}\text { McLean } \\
\text { and } \\
\text { Gribble }\end{array}$ & 1985 & Earths deposited in freshwater lakes by friable carbonate materials \\
\hline Qahwash & 1989 & Sediments of calcareous type \\
\hline Mitchell & 1993 & $\begin{array}{l}\text { Ranges between clean calcium carbonate to the mixture of calcium carbonate } \\
\text { with organic matter and mud formed from bio-chemical formation }\end{array}$ \\
\hline Aiban & 1994 & Calcareous sediment of fine grained nature \\
\hline
\end{tabular}

\section{Potential Problem of Marl Soil}

Marl is a swelling soil that gives a significant increase in bulk volume when water is present, as it gives high shrinkage ratio on drying. Swelling is dependent on the dry unit weight and increasing clay containing active clay minerals, such as; Almontmurilonat (Montmorillonite). These formations are characterized by hardness, higher shear strength in dry condition; and the solid soil gradually loses these properties with increasing humidity.

Marl soils usually have very high moisture content, low dry density, low bearing capacity and low strength in shear cases. These nature makes them "problematic soils" that are not suitable for pavement related subgrades, and slopes. Due to these reasons very limited research work has been accomplished in the Midwest of Saudi Arabia with marls.

\section{Materials and Methods}

\subsection{Marl Characterizations}

Characterization of the Marl is crucial to deal with all related geotechnical engineering problems. Subsequent sections describe their typology, formation, physical, chemical, and mechanical properties and feedback to some geotechnical field and laboratory tests.

\subsection{Types of Marl Soil}

Marl soils are fine and coherent marine type of sedimentary deposits which mainly consisting of clay and calcium carbonate $(\mathrm{CaCO} 3$, varying proportion 30\% - 70\%). This particular soil cover an extensive area of the south east, east and west of Algiers where much of the urban and regional development is ongoing [2]. The main marl soil deposit found to be more than $200 \mathrm{~m}$ in thickness forming commonly a homogeneous and massive substratum. Their geotechnical behavior mainly depends on the type of clay minerals and the amount of carbonate. Marl soils cane be classified in three categories, based on the intensity of weathering:

- Intact marls

- Intermediate marls

- weathered marls

\subsection{Availability of Marl Soils in Saudi Arabia}

Marl type of soil is plentiful in eastern Saudi Arabia. The places can be listed as: Abqaiq, Dammam, Dhahran, Abu Ali, Berri, Fadhli, Hofuf, Jubail, Safaniyah and Abu Hadriyah (as in Fig. 1). Eastern Saudi Arabian Marls, vary in range greatly from one place to other in terms of color, plasticity, engineering properties and physical-chemical composition. The color of Marl in the Saudi Arabian Eastern part are mainly white, milky, light and dark gray, yellow, pink and brown types. 


\subsection{Formation of Marl Soil}

Marl is a clayey stone mud consists of mud, silt and lime, (CaCO3). The geotechnical studies [2] of such soils have shown that the marls are fine grained soils with low strength and low permeability; contains a substantial amount of montmorillonite that increases in the weathered horizons, illite and smectite in varying proportion. The mineralogical part make marls very much sensitive to water, resulting in high changes in volume (shrinkage and swelling) and loss in strength resulting in a very unstable geological formation. This instability affects structures which constructed on such soil formations where wide tension crakes can be visible. The fact also leads instability of slope when the gradient exceeds $10 \%$.

\subsection{Chemistry in Marl Formation}

Table 2 shows the chemical composition for marl soils. Varieties of metal in the form of oxide are visible in the experimental results which may cause the marl soil to be more sensitive to moisture and other effects. The assessment of chemical tests carried out for marl soil by Al-Amoudi, et al. [2], Clayey Marl [10] and Corinth marl [11] have been illustrated which show the deviation in ingredients in marl soil.

Table 2. Chemical composition of clayey marl.

\begin{tabular}{|l|l|l|l|}
\hline Oxide & Clayey Marl [10] & Corinth marl [11] & Al-Amoudi, et al. [2] \\
\hline $\mathrm{SiO}_{2} \%$ & 18.5 & 17.5 & 15 \\
\hline $\mathrm{Al}_{2} \mathrm{O}_{3} \%$ & 6.9 & 1.5 & \\
\hline $\mathrm{KAlSi} 3 \mathrm{O} 8$ & & & 8 \\
\hline $\mathrm{Fe}_{2} \mathrm{O}_{3} \%$ & 1.8 & 1.1 & \\
\hline $\mathrm{CaO} \%$ & 30.3 & $42.5(30-52)$ & \\
\hline $\mathrm{CaCO} 3$ & & & 75 \\
\hline $\mathrm{MgO} \%$ & 2.91 & 1.5 & \\
\hline $\mathrm{TiO}_{2} \%$ & 0.3 & & \\
\hline $\mathrm{K}_{2} \mathrm{O} \%$ & 0.9 & 0.3 & \\
\hline $\mathrm{P}_{2} \mathrm{O}_{5} \%$ & 0.12 & & \\
\hline $\mathrm{Na}_{2} \mathrm{O} \%$ & & 0.6 & \\
\hline $\mathrm{CaSO}_{2} \% \mathrm{H} 2 \mathrm{O}$ & & & \\
\hline
\end{tabular}

\subsection{Structural and Textural Character}

Physical, chemical and mineralogical properties of Marl Soil observed in existing researches are shown in Tables 3, 4 and 5 below which indicate the distinct character of it: 
Table 3. Summary of marl classifications based on physical properties.

\begin{tabular}{|c|c|c|c|c|c|c|c|c|c|c|}
\hline 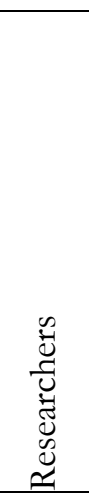 & 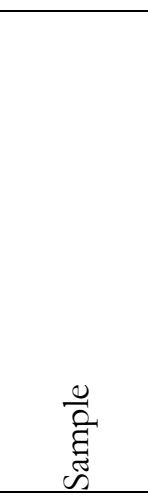 & 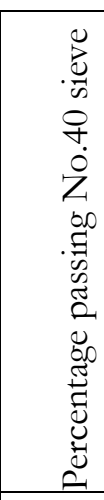 & 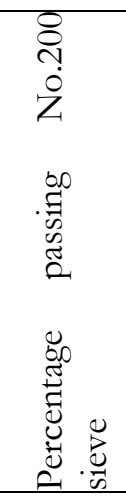 & 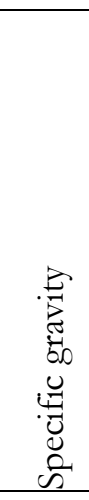 & 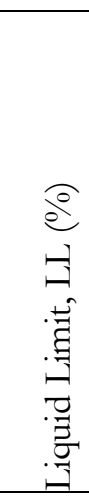 & 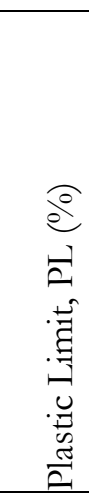 & 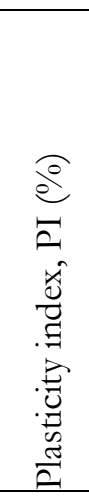 & 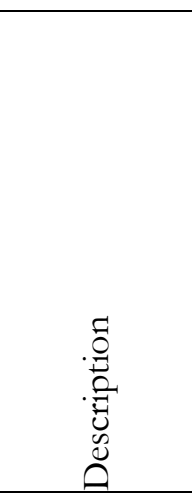 & 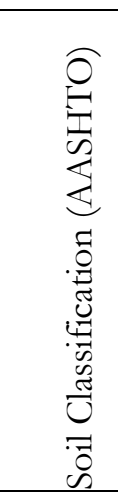 & 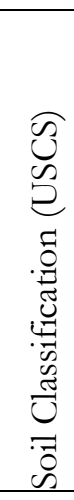 \\
\hline [12] & & 67 & 3 & 2.68 & -- & -- & NP & $\begin{array}{l}\text { Uniform } \\
\text { fine sand }\end{array}$ & A-3 & SP \\
\hline [13] & & 26 & 14 & 2.71 & 47 & 45 & 2 & White Marl & A-1-a & GM \\
\hline [2] & & & & 2.78 & & & NP & $\begin{array}{l}\text { coarse- } \\
\text { grained }\end{array}$ & A-2 & SM \\
\hline [14] & & 57 & 33 & 2.7 & 25 & 31 & NP & $\begin{array}{l}\text { fine-graded } \\
\text { soil } \\
\text { associated } \\
\text { with } \\
\text { significant } \\
\text { percentage } \\
\text { of silt- clay } \\
\text { particles }\end{array}$ & A-2-4 & -- \\
\hline [9] & & -- & -- & 2.73 & 21 & 20 & 1 & -- & A-1-a & GP \\
\hline \multirow{15}{*}{ [8] } & $\begin{array}{l}\text { M- } \\
\text { ABH1 }\end{array}$ & -- & 10.72 & 2.84 & 21.5 & 20 & 1.5 & -- & $A-1-b$ & $\begin{array}{l}\text { SP- } \\
\text { SM }\end{array}$ \\
\hline & $\begin{array}{l}\mathrm{M}- \\
\mathrm{ABH} 2\end{array}$ & -- & 3.44 & 2.73 & 21 & 19.5 & 1.5 & -- & $A-1-b$ & SP \\
\hline & $\begin{array}{l}\text { M- } \\
\text { ABH3 }\end{array}$ & -- & 1.01 & 2.8 & -- & -- & NP & -- & A-1-a & SP \\
\hline & $\begin{array}{l}\text { M- } \\
\text { ABH4 }\end{array}$ & -- & 0.22 & 2.8 & -- & -- & NP & -- & A-1-a & GP \\
\hline & $\begin{array}{l}\text { M- } \\
\text { ABH5 }\end{array}$ & -- & 4.78 & 2.8 & -- & -- & NP & -- & A-1-a & GW \\
\hline & $\begin{array}{l}\text { M- } \\
\text { ABH6 }\end{array}$ & -- & 7.45 & 2.73 & -- & -- & NP & -- & A-1-b & $\begin{array}{l}\text { SP- } \\
\text { SM }\end{array}$ \\
\hline & $\begin{array}{l}\text { M- } \\
\text { ABH7 }\end{array}$ & -- & 4.19 & 2.81 & 38.4 & 32.5 & 5.9 & -- & A-2-4 & $\mathrm{SP}$ \\
\hline & $\begin{array}{l}\text { M- } \\
\text { ABH8 }\end{array}$ & -- & 1.92 & 2.81 & -- & -- & NP & -- & A-1-a & SP \\
\hline & $\begin{array}{l}\text { M- } \\
\text { ABH9 }\end{array}$ & -- & 2 & 2.73 & 21 & 19.5 & 1.5 & -- & A-1-a & GP \\
\hline & M-ABQ & -- & 18.94 & 2.71 & 51.1 & 48.7 & 2.4 & -- & A-1-a & GM \\
\hline & $\begin{array}{l}\text { M- } \\
\text { ABQR1 }\end{array}$ & -- & 7.21 & 2.72 & 99.7 & 66.7 & 33 & -- & A-2-7 & $\begin{array}{l}\text { GP- } \\
\text { GM }\end{array}$ \\
\hline & $\begin{array}{l}\text { M- } \\
\text { ABQR2 }\end{array}$ & -- & 9.63 & 2.85 & -- & -- & NP & -- & $A-1-b$ & $\begin{array}{l}\text { SP- } \\
\text { SM }\end{array}$ \\
\hline & $\begin{array}{l}\text { M- } \\
\text { ABQR3 }\end{array}$ & -- & 0.93 & 2.73 & 34.9 & 30 & 4.9 & -- & A-2-4 & GP \\
\hline & $\begin{array}{l}\text { M- } \\
\text { AIND }\end{array}$ & -- & 9.54 & 2.78 & 72.5 & 69.4 & 3.1 & -- & A-1-a & $\begin{array}{l}\text { SP- } \\
\text { SM }\end{array}$ \\
\hline & M- & \begin{tabular}{|l}
-- \\
\end{tabular} & 7.31 & 2.92 & 105 & 82.7 & 24.2 & -- & A-2-7 & SW- \\
\hline
\end{tabular}




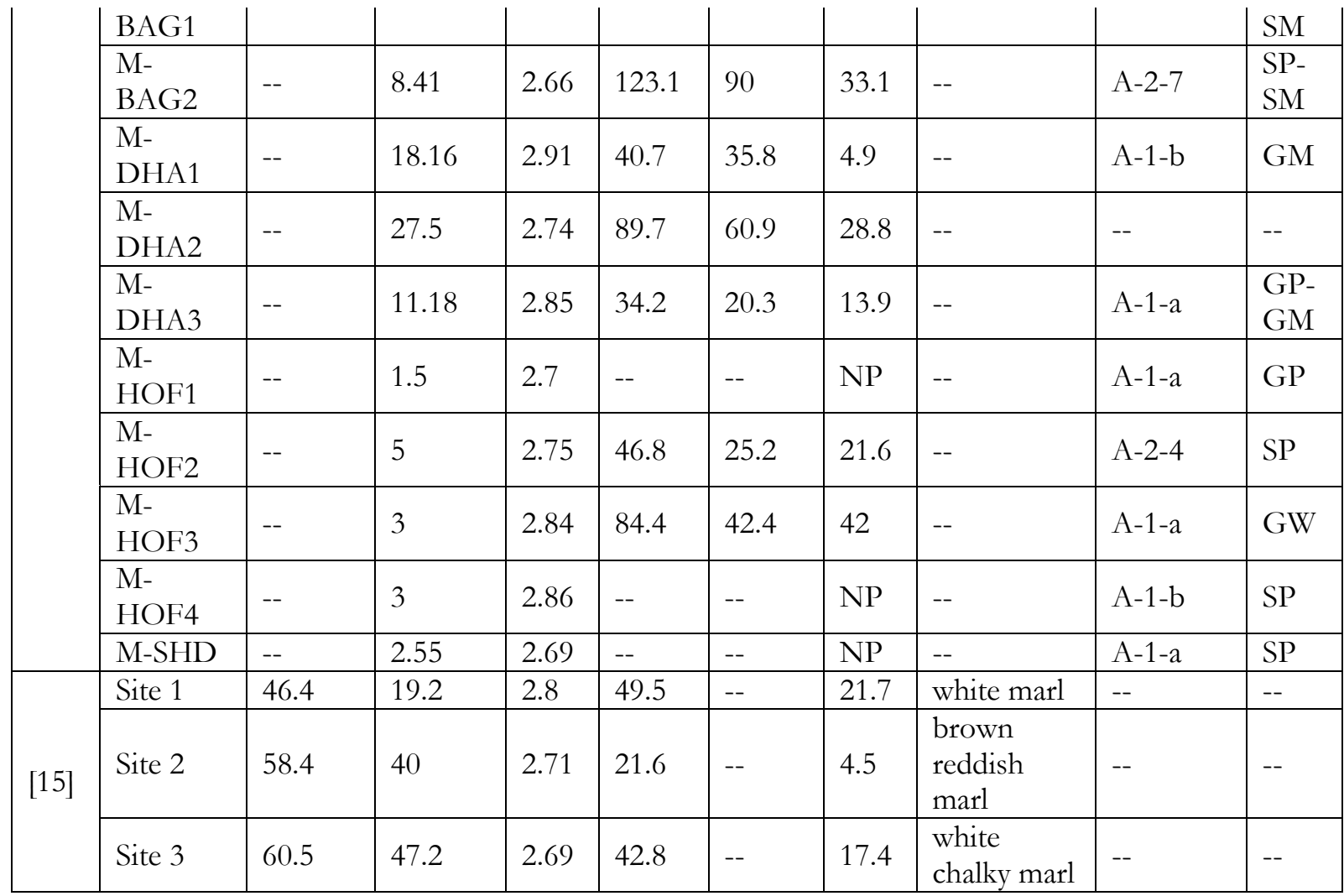

Table 4. Chemical analysis of some marl samples [9].

\begin{tabular}{|l|l|l|l|l|l|l|l|l|}
\hline \multirow{2}{*}{ Marl } & \multicolumn{2}{|l|}{$\mathbf{C a}^{+2+}(\mathbf{\%})$} & \multicolumn{2}{l|}{$\mathbf{M g}^{2+}(\mathbf{\%})$} & \multicolumn{2}{l|}{$\mathbf{C a C O}_{3}$} & \multicolumn{2}{l|}{$\mathbf{C a M g}\left(\mathbf{C O}_{3}\right)_{2}$} \\
\cline { 2 - 9 } & $-\# 40$ & $-\# 100$ & $-\# 40$ & $-\# 100$ & $-\# 40$ & $-\# 100$ & $-\# 40$ & $-\# 100$ \\
\hline M-ABH9 & 42.8 & 56.3 & 3.8 & --- & 39.0 & 56.3 & 3.8 & --- \\
\hline M-ABQR3 & 28.0 & 34.5 & 25.8 & 23.6 & 2.2 & 10.9 & 25.8 & 23.6 \\
\hline M-SHD & 37.5 & 62.6 & --- & --- & 37.5 & 62.7 & --- & --- \\
\hline
\end{tabular}

Table 5. Mineralogical composition of some marl samples [9].

\begin{tabular}{|l|l|l|l|l|l|l|l|l|}
\hline \multirow{2}{*}{ Marl } & \multicolumn{2}{|l|}{ Calcite (\%) } & \multicolumn{2}{l|}{ Dolomite (\%) } & \multicolumn{2}{l|}{ Quartz (\%) } & \multicolumn{2}{l|}{ Others* (\%) } \\
\cline { 2 - 10 } & $-\# 40$ & $-\# 100$ & $-\# 40$ & $-\# 100$ & $-\# 40$ & $-\# 100$ & $-\# 40$ & $-\# 100$ \\
\hline M-ABH9 & 96 & 80 & 1 & 1 & 3 & 18 & --- & 1 \\
\hline M-ABQR3 & 5 & 13 & 20 & 38 & 72 & 45 & 3 & 4 \\
\hline M-SHD & 28 & 71 & --- & --- & 70 & 23 & 2 & 6 \\
\hline
\end{tabular}

*Including elite, sepiolite, montmorillonite and gypsum.

\#40: passing sieve number 40

\#100: passing sieve number 100

\section{Engineering Properties of Marl Soil}

Several investigations have been conducted by researchers, including: field tests and laboratory tests. Some of the important results are summarized in the following sections. 


\subsection{Field Test on Marl}

In order to learn the stratigraphy and subsurface condition, mainly two field tests: [Standard Penetration Test (SPT-N) and California Bearing Ration (CBR)] data obtained from various researchers were presented and examined. CBR test conducted by Al-Amoudi et al. (2010) indicates that Marl is very weak and extremely vulnerable to failure on flooding. Naturally existing Marls have very low CBR (3 to 4), and are found to reduce by $50 \%$ on flooding indicating its very loose nature. The physical and mechanical properties of Marl soil are presented in Table $6 \& 7$ with the standard deviation (S.D.). The SPT, cohesion and angle of friction values indicates the weak nature of Marl soil.

Results obtained from Al-Amoudi, et al. [2] show that the physical character and parameters, such as plasticity and changes in volume are greatly reduced after the addition of very small proportion of cement or lime. The compressibility tests also show that cement and lime increase its stiffness and CBR and Unconfined Compression Strength (UCS) values are greatly enhanced

\subsection{Laboratory Tests}

The percentage of calcium carbonate $\left(\mathrm{CaCO}_{3}\right)$ of typical soil samples was determined by three different methods: (1) LOI (Loss on Ignition); (2) TGA (Thermo-Gravimetric Analysis); and (3) chemical reaction as per ASTM C 25 (14): XRD, Atterberg condition limit tests and pH were also conducted for the collected soil samples.

Furthermore, moisture-density relationship, soil fabric, CBR-CIV correlation and CBR, unconfined compressive strength, tri axial compression test, one dimensional compressibility, effect of delay in compaction and moisture content on UCS, as well as durability are also investigated in several studies. The experimental work was done on white marl [3] collected from the Abqaiq region situated nearly $60 \mathrm{~km}$ South West of Dhahran, Saudi Arabia. The classification tests were accomplished according to the ASTM standards. The various properties obtained from testing are shown in Table 3. The soil was classified as A-1a as per AASHTO classification system and GM according to USCS.

Table 6. Physical and mechanical attributes of clayey type of marl [3].

\begin{tabular}{|l|l|}
\hline Specific Parameter & $\begin{array}{l}\text { Clayey } \\
\text { Marl }\end{array}$ \\
\hline $\mathrm{pH}$ & 8.1 \\
\hline Specific gravity $\left(G_{\mathrm{s}}\right)$ & 2.65 \\
\hline Group Index & 21.15 \\
\hline Liquid limit & 44 \\
\hline Plasticity index (LL-PL) & 23 \\
\hline Percentage Passing \#200 & 88 \\
\hline $\begin{array}{l}\text { Percentage of Clay } \\
\text { Fraction }\end{array}$ & 80 \\
\hline
\end{tabular}

Specific gravity of marl soil was reported as 2.69 by Aal and Al-Homidy [16]. El Howayek, et al. [17] dealt with two types of Marl soil namely soil M (silty loam) and soil C (silty clay) which characteristics have been explained with the allowed statistical deviation in Table 7. Moreover, a number of 32 samples had been taken in experimental tests of marl soil by Lamas, et al. [18] leading to the sequent statistical consequences as in Table 8. 
Table 7. Deviation of physical and mechanical attributes of marl [17].

\begin{tabular}{|l|l|l|l|l|}
\hline & \multicolumn{2}{|c|}{ Soil M } & \multicolumn{2}{l|}{ Soil C } \\
\hline & Range & Mean \pm SD & Range & Mean \pm SD \\
\hline Organic Content (\%) & $2.0-4.3$ & $3.1 \pm 0.6$ & $1.7-3.0$ & $2.5 \pm 0.4$ \\
\hline CaCO3 $(\%)$ & $35.9-64.4$ & $54.0 \pm 7.4$ & $33.7-41.8$ & $37.0 \pm 2.9$ \\
\hline Water Content, wL $(\%)$ & $50.5-68.5$ & $60.9 \pm 6.0$ & $36.6-52.2$ & $42.1 \pm 5.2$ \\
\hline Plastic Limit, PL (\%) & $29.0-40.6$ & $34.6 \pm 3.5$ & $18.8-25.5$ & $21.6 \pm 2.3$ \\
\hline Liquid Limit, LL (\%) & $61.7-78.8$ & $67.5 \pm 5.2$ & $40.1-52.4$ & $47.5 \pm 4.2$ \\
\hline Silt Content (\%) & $72.0-82.0$ & $77.6 \pm 3.0$ & $54.0-66.0$ & $61.0 \pm 5.5$ \\
\hline Clay Content (\%) & $15.0-23.0$ & $18.3 \pm 2.8$ & $33.0-45.0$ & $38.3 \pm 5.3$ \\
\hline Specific Gravity, Gs & $2.68-2.80$ & $2.71 \pm 0.03$ & $2.76-2.82$ & $2.79 \pm 0.02$ \\
\hline Void Ratio, e & $1.4-1.9$ & $1.7 \pm 0.1$ & $1.1-1.5$ & $1.2 \pm 0.1$ \\
\hline Total unit weight, $\gamma \mathrm{kN} / \mathrm{m} 3$ & $15.5-16.8$ & $15.9 \pm 0.4$ & $16.8-18.3$ & $17.6 \pm 0.5$ \\
\hline Degree of saturation & $95.3-99.8$ & $97.9 \pm 1.4$ & $93.2-99.0$ & $97.4 \pm 1.9$ \\
\hline Salt concentration $(\mathrm{g} / \mathrm{l})$ & $2.1-3.8$ & $3.0 \pm 0.5$ & $2.2-5.1$ & $3.6 \pm 1.2$ \\
\hline Salt concentration $(\mathrm{g} / \mathrm{kg})$ & $1.4-2.2$ & $1.9 \pm 0.2$ & $0.9-1.9$ & $1.5 \pm 0.4$ \\
\hline pH & $7.5-7.9$ & $7.8 \pm 0.1$ & $7.6-7.9$ & $7.8 \pm 0.1$ \\
\hline
\end{tabular}

Table 8. Statistical analysis of marl physical and mechanical characteristic [18].

\begin{tabular}{|c|c|c|c|c|c|}
\hline Variables & Units & Values & & & \\
\hline & & Highest & Mean & Lowest & S.D. \\
\hline Natural water content & $\%$ & 22.5 & 15.8 & 10.9 & 3.1 \\
\hline Largest size & $\mathrm{Mm}$ & 20.0 & 10.0 & 2.0 & 7.1 \\
\hline Fraction $<0.08 \mathrm{~mm}$ & $\%$ & 98.9 & 90.8 & 71.0 & 6.4 \\
\hline Greatest density & $\mathrm{Tn} / \mathrm{m} 3$ & 1.82 & 1.71 & 1.62 & 0.05 \\
\hline Optimum moisture content & $\%$ & 22.2 & 18.3 & 15.2 & 1.6 \\
\hline Liquid limit & $\%$ & 57.6 & 43.8 & 31.0 & 5.0 \\
\hline Plastic limit & $\%$ & 25.5 & 18.9 & 15.8 & 2.3 \\
\hline Plasticity Index & $\%$ & 34.5 & 25.0 & 15.2 & 3.9 \\
\hline Carbonates & $\%$ & 72.3 & 53.5 & 32.2 & 8.68 \\
\hline Quart & $\%$ & 25.3 & 20.3 & 0.0 & 10.26 \\
\hline Sulphates & $\%$ & 3.55 & 0.92 & 0.01 & 1.00 \\
\hline Dispersability & $\mathrm{X} 10^{-6} \mathrm{~m}^{3} / \mathrm{s}$ & 3.77 & 2.42 & 1.58 & 0.89 \\
\hline Permeability & $\mathrm{X} 10^{-9} \mathrm{~m}^{3} / \mathrm{s}$ & 54 & 1.94 & 0.025 & 9.83 \\
\hline Specific Gravity & $\mathrm{Tn} / \mathrm{m}^{3}$ & 2.75 & 2.68 & 2.52 & 0.05 \\
\hline Cohesion & $\mathrm{kPa}$ & 4.6 & 1.9 & 1.0 & 0.9 \\
\hline Angle of Friction & Degrees & 35.0 & 24.8 & 15.5 & 3.9 \\
\hline Preconsolidation pressure & $\mathrm{kPa}$ & 21 & 13 & 8 & 3 \\
\hline Vertical consolidation constant & $\mathrm{X} 10^{-8} \mathrm{~m}^{2} / \mathrm{s}$ & 8 & 2.89 & 0.12 & 1.67 \\
\hline Clay fraction & $\%$ & 45.3 & 39.5 & 30.1 & 6.6 \\
\hline Activity & & 0.74 & 0.60 & 0.30 & 0.10 \\
\hline Void ratio & & 0.650 & 0.522 & 0.420 & 0.048 \\
\hline
\end{tabular}

The mineralogy attributes of the marl soil was obtained by X-ray diffraction (XRD) technique [8]. The field representative samples on material passing on US sieve No. 40 and sieve No. 100 were examined. Powder type samples were made by crushing the marl material into fine grained powder $(<50 \# \mathrm{~m})$. The different minerals were identified using the powder XRD analysis. The predominant percentages of nonclay minerals are dolomite, calcite and quartz with varying amount. A small number in percentages of montmorillonite as well as other clay minerals were found in the samples.

Aiban [13] performed laboratory investigation to evaluate the geotechnical engineering properties of selected Marl collected from Abqaiq, Eastern Saudi Arabia. It was found that the moulding moisture content percentage significantly affects the engineering related properties of marl. The addition of only $2 \%$ 
Portland cement improves the CBR values significantly. His results also showed that the permeability increased with the permeation period due to leaching.

\section{Stabilization of Marl Soils}

Several stabilization methods have been utilized for the enhancement of Marl soil properties. Following stabilizations procedures are employed in improvement of Marl Soil in Eastern Saudi Arabia.

\subsection{Chemical Stabilization}

Fly ash utilization is common in soil stabilization in recent literatures [19-25]. Al-Malack, et al. [26] performed tests on stabilizing two types of local Saudi soils (sand and marl) using Fuel Oil Fly ash (FFA). $5 \%, 10 \%$ and $15 \%$ of FFA was added to both sand and marl with and without addition of $5 \%$ Portland cement. It was concluded that marl stabilized with 5\% FFA and 5\% of cement satisfied the ACI strength requirements. Increasing the percentage of FFA to $10 \%$ and $15 \%$ reduced the mixture strength below the ACI requirement.

Foamed asphalt technology was effectively used in road bases constructed from local Saudi marl soils as well as from Reclaimed Asphalt Pavements (RAP) [27]. Abdullah and Wahhab [28] concluded that indirect tensile strength (ITS), shear strength and marshal stability for marl, sand and Marl soil stabilized with foam sulfur asphalt showed better results as compared to conventional foam asphalt. The ITS was improved by $9.4 \%$ to $17 \%$, shear strength by $14 \%$ and marshal stability by $76 \%$ to $250 \%$.

Qahwash [15] performed a comprehensive laboratory study to evaluate the geotechnical engineering properties of natural fined grained calcareous sediments in Dhahran and Dammam areas. Tests indicated that the fine-grained calcareous sediments possess a low bearing capacity. The influence of saturation was characterized by a reduction in the bearing capacity amounting to one-third the original value. It was recommended that sand not less than $70 \%$ by weight be added to the natural fine-grained calcareous sediment to make it a suitable sub-base material. This is desirable by contractors who prefer to work with non-plastic earth materials rather than plastic ones. An increase in sand content increased the maximum dry density and decreased the optimum moisture percent. The rate of the California Bearing Ratio (CBR) value were also observed to be increased significantly with large percentage of sand. The availability of huge quantities of sand in the area makes this procedure more economical.

\subsection{Chemical Stabilization Using Cement}

Wahhab and Asi [14] investigated and reported the combined effect of Portland cement (PC) and lime types of additive on the shear strength $(\mathrm{Qu})$ for compacted marl. It was found that addition of the cement/lime contents resulted in an increment in the shear strength of comp acted Marl, and also soaking of the untreated marl samples resulted in total failure. The addition of marl with liquid asphalt prevented the loss of total shear strength of compacted samples when soaked. Their experimental found that as the percentage of PC was increased, the dry and soaked shear strengths of marl also improved. It was reported in the literature that emulsified asphalt is more operative when a low percentage of PC is used due to the accelerated effect of curing. The addition of $2 \%$ lime to Marl (emulsion treated) slightly improved the amount of shear strength. This consequence was found to be reversed when lime was increased from $2 \%$ to $4 \%$ by weight.

Aiban, et al. [9] carried out a comprehensive laboratory testing program for evaluating the performance of cement added and stabilized marl soil mixtures under different environmental exposure conditions. Depend on the laboratory test results and the traffic data, four sections of base courses were constructed, two of them without any additives and two with $4 \%$ cement. The continual monitoring as well as evaluation of the 4 sections for around four years indicated that the cement-treated road cross sections exhibited better result over the untreated sample. As compared to the untreated sections, that experienced different forms of deterioration within a few months duration after the construction, the stabilized sections were found to be in an excellent condition until now. Also it was found that the cement additive stabilized marl exhibited CBR values which are more than the lime treated one. Due to the lack of any material (contains pozzolanic substances) in the selected marl, lime was not able to produce higher strength. Furthermore, 
from an economic view point, hydrated lime costs about 2.5 times higher than cement in the local Saudi market. Hence, PC was potentially selected as the chemical additive that can be used to stabilize the marls.

Al-Amoudi, et al. [2] carried out laboratory investigations focusing on marl improvement to be used as a road bases. Results showed that cement was better than lime for both in terms of durability and requirements of strength improvement.

\subsection{Stabilization Using Sand}

Aiban, et al. [8] recommended stabilizing marl of Abu Hadriyah area by mechanical stabilization, by replacing part of Marl Soil with equivalent amount of quartz sand. This showed little increase in maximum dry density, little decrease in optimum moisture content and no change in CBR value. The author also found that $5 \%$ cement to 30\% Baggah Sand is the best ratio for improving Abu Hadriyah, Abqaiq Marl with respect to strength and durability.

\subsection{Stabilization Using Lime}

Al-Amoudi, et al. [2] showed that lime-treated marl soil mixtures (subjected to exposed condition) exhibits more shear strength as compared to the sealed samples. They observed it for both sealed and exposed conditions unconfined Compression Strength (UCS) values for 90-days duration. Lime-marl (by weight $5 \%$ mixtures prepared at the dry side of the optimum moisture were found to be $1620 \mathrm{kPa}$ and $1975 \mathrm{kPa}$, respectively. The equivalent values were found to be $2307 \mathrm{kPa}$ and $2210 \mathrm{kPa}$ for $7 \%$ lime mixed samples. Likewise, the UCS for the unsealed and lime-treated marl at optimum moisture content $\left(\mathrm{w}_{\mathrm{opt}}\right)$ revealed higher strength as compared to the sealed sample. The strength values for respective $5 \%$ lime sample were respectively 1513 and $3446 \mathrm{kPa}$, for the sealed and exposed samples. The marl soil treated with lime displayed a more significant strength value reduction for the 5\% and $7 \%$ lime contents on the wet side of the optimum, under the sealed conditions with the strength values of 696 and $809 \mathrm{kPa}$, respectively. Still, the strength of the exposed marl samples remained almost in the equal range as on the dry side of optimum. The strength for the 5\% and 7\% lime agent contents samples was found to be 1922 and 2136 $\mathrm{kPa}$, respectively. Ultimately, the strength value was not expressively affected by the percentage of the lime dosages and the laboratory results, though, were more subtle to the procedure for curing.

\subsection{Stabilization Using Foamed Asphalt}

Qahwash [15] carried out a stabilization program on Marl using emulsified and cutback asphalts with small percentages of lime and cement $(2 \%$ and $4 \%)$ to enhance the early age properties of Marl and to study the effect of different stabilizers including lime, cement, liquid asphalt and their combinations on the engineering properties of Marl Soil obtained from Dhahran. The effect of type and percent of additive, curing time, confining pressure and water content were investigated. Their results which were primarily based on tri-axial and unconfined compressive strength tests indicated that both types of liquid asphalts were only effective in reducing the stability loss upon saturation but not in enhancing the strength properties. Besides, the addition of either lime or cement increased the shear strength of all compacted samples, although cement was reported to be more effective than lime, especially when emulsified asphalt is used. They stated that optimum properties are obtained when Marl is treated with emulsified asphalt, especially when a small percentage of PC is added.

Table 9. Summary of Characterization of Eastern Saudi Marl [9].

\begin{tabular}{|l|l|}
\hline Property & Marl \\
\hline Typical Construction Problems & $\begin{array}{l}\text { Acute water sensitivity, high } \\
\text { variability, grain crushing, inaccurate } \\
\text { characterization procedures }\end{array}$ \\
\hline Plasticity Index* & NP to a PI of 40 \\
\hline
\end{tabular}




\begin{tabular}{|c|c|c|}
\hline $\begin{array}{l}\text { Gradation* } \\
-C_{u} \\
-C_{c}\end{array}$ & $\begin{array}{l}\text { Highly } \\
13-200 \\
0.1-40\end{array}$ & Variable \\
\hline \% Passing ASTM Sieve No.200 & $\begin{array}{lcr}1-19 & \text { for } \text { dry } \\
10-44 \text { for washed sieving }\end{array}$ & sieving \\
\hline $\begin{array}{l}\text { Classification* } \\
\text { USCS } \\
\text {-AASHTO }\end{array}$ & $\begin{array}{l}\text { GW } \\
\text { A-1-a to A-2-7 }\end{array}$ & SP-SM \\
\hline Specific Gravity* & $2.66-2.92$ & \\
\hline 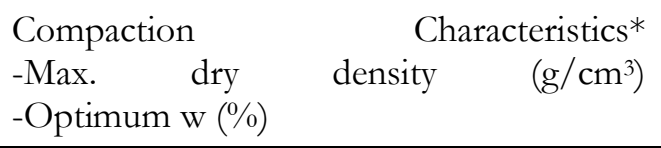 & $\begin{array}{l}1.67-2.2 \\
6.4-18.6\end{array}$ & \\
\hline Peak Friction Angle (deg.)* & ----- & \\
\hline Mineralogical Composition (\%) & $\begin{array}{l}\text { Calcite } \\
\text { Dolomite } \\
\text { Quartz } \quad(3-72)\end{array}$ & $\begin{array}{l}(5-96) \\
(0-20)\end{array}$ \\
\hline Permeability, $\mathrm{m} / \mathrm{s}$ & $\begin{array}{l}\mathrm{k}_{\min }=1 * 10^{-10} \\
\mathrm{k}_{\max } \text { at } 95 \% \text { comp. }=6.6^{*} 10^{-7}\end{array}$ & \\
\hline $\begin{array}{llrr}\text { CBR* } & \text { (as } & \text { molded) } \\
\text { Max.CBR @ (as molded) } & € \\
-3 \% & & & \text { cement } \\
-5 \% & & & \text { cement } \\
-7 \% & & & \text { cement } \\
-10 \% \text { cement } & & & \end{array}$ & $\begin{array}{l}50-205 \\
134-253 \\
620-745 \\
895-1014 \\
940-1368\end{array}$ & \\
\hline 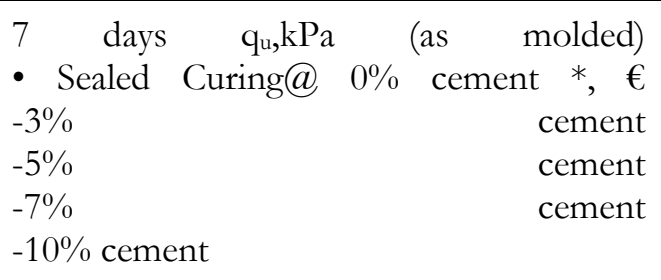 & $\begin{array}{l}241-337 \\
2498-3908 \\
3560-6361 \\
3854-6886 \\
-------\end{array}$ & \\
\hline 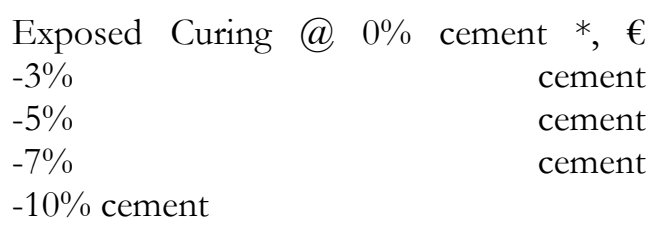 & $\begin{array}{l}1841-2604 \\
4495-6002 \\
5558-8769 \\
5606-8900 \\
--------\end{array}$ & \\
\hline
\end{tabular}

* Original Soils (no improvement)

$\mathrm{q}_{\mathrm{u}}=$ unconfined compressive strength

\section{Results and Discussion}

\subsection{Salient Characteristics of Marl}

Marl soil could be classified as GW to SP-SM according to USCS and A-1-a to A-2 according to AASHTO soil classification systems based on the plasticity and grain-size analysis results. Specific gravity of the soil was reported within the range of 2.66-2.92. Marl soil contains a high variation of calcite (5\%-96\%), quartz (3\%-72\%) and dolomite (0-20\%). The high percentage of quartz and calcite are responsible for coarsegrained nature and non-plastic behavior marl has been postulated. The optimum water content percentage varied from $6.4 \%$ to $18.6 \%$. Without any cement addition, the maximum dry density varied from $1.67 \mathrm{~g} / \mathrm{cm} 3$ for the soil and $10 \%$ cement content the dry density value reached to a maximum value of 
about $2.2 \mathrm{~g} / \mathrm{cm} 3$. Without any stabilizer the maximum CBR was found to be 108 . Though, the CBR increased to 1315 consistent to $10 \%$ addition of cement to the marl soil. It was found that the delay in compaction work may result in reduce strength for both curing conditions for the samples cured under sealed and exposed conditions. The reduction in strength value was more distinct at beginning, and, thereafter, soil got stabilized after the two hours of delay, especially for the sealed and cured condition. It is the fact that when cement agent is added to the un-stabilized soil sample and then compacted without delay, the chemical agent hydrates after mixing and compaction and then develops more effective strength than that compacted with delay. Table 9 summarizes the results of marl soil properties tested under the described scheme.

Table 10. Stabilization outcome of Eastern Saudi Marl [9].

\begin{tabular}{|c|c|}
\hline Property & Marl \\
\hline Effect of Delay in Compaction $€$ & $\begin{array}{l}\text { Delay should not exceed } 2 \text { hrs from } \\
\text { mixing }\end{array}$ \\
\hline $\begin{array}{lr}\text { Durability (Weight Loss)\% ASTM D } 559 @ \text { @ } \\
-3 \% & \text { cement } \\
-5 \% & \text { cement } \\
-7 \% & \text { cement } \\
-10 \% \text { cement } & \end{array}$ & $\begin{array}{l}1.6-2.5 \\
0.7-1.3 \\
0.4-0.9 \\
------\end{array}$ \\
\hline $\begin{array}{lrr}\text { Slake Durability } & \text { (Weight } & \text { Loss) } \% \text { cement } \\
-3 \% & & \text { cement } \\
-5 \% & & \text { cement } \\
-7 \% & & \\
-10 \% \text { cement } & & \end{array}$ & $\begin{array}{l}1.3-2.7 \\
0.6-1.0 \\
0.3-0.9 \\
-----\end{array}$ \\
\hline 7 days Modulus of Resilience $\left(\mathrm{M}_{\mathrm{R}}\right) \mathrm{Mpa}$ & 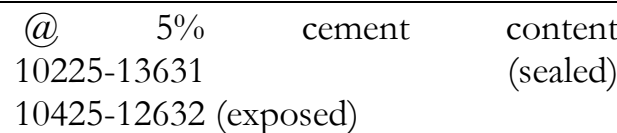 \\
\hline Optimum Asphalt Content $€$ & $\begin{array}{l}-6 \% \text { emulsion }(2 \% \text { premixing water }+2 \\
\text { to } 4 \% \quad \text { added } \quad \text { water }) \\
-6 \% \text { cutback asphalt }\end{array}$ \\
\hline Dry Stability at $€$ & $\begin{array}{ll}-20 \mathrm{kN} \text { at optimum emulsion }+0 \% & \\
\text { cement } & -33 \mathrm{kN} \\
\text { at optimum }+2 \% \quad \text { cement } \\
-15 \mathrm{kN} \text { at optimum }+0 \% \text { cement }\end{array}$ \\
\hline Wet Stability at $€$ & $\begin{array}{l}-7.5 \mathrm{kN} \text { at optimum emulsion }+0 \% \\
\text { cement } \\
\text { at optimum }+28 \mathrm{kN} \\
\end{array}$ \\
\hline Recommended Stabilization Method & -Cement \\
\hline
\end{tabular}

$€$ : For the soils for detailed investigation

\subsection{Consequences of Marl Soil Stabilization}

Compacting with the stabilized materials enhances the properties of Marl soil which is expected in improve subgrade in prospective construction. The results of stabilization techniques for marl are summarized in Table 10. The result shows the strength, stability perspective at various condition with different cement and emulsion contents. 


\subsection{Durability Assessment}

The long duration serviceability of any stabilized soil assessment considered to be an integral part of any kind of soil stabilization platform. The durability assessment for Saudi Arabian marl soil results are presented in Fig. 2 with material loss in weight and the stabilizer dosages. On the instance of marl treating with $5 \%$ and $7 \%$ lime the material loss changed significantly.

According to ASTM test slake tests the loss counted as $9.7 \%$ and $13.9 \%$, respectively for $5 \%$ lime content. However, the material loss was found to be much less ( $8.2 \%$ and $4.0 \%$, respectively). The same tendency was also noted for the $7 \%$ lime treated marl mixtures.

For $5 \%$ cement treated marl, the loss in weight was significantly reduced to $2.6 \%$ and $4.5 \%$ for the both two methods. But, with 7\% cement treatment, the difference between the two techniques was found not to be significant, and the loss in weight being less than $2 \%$ for the both methods. The data affirms the dominance of PC for improving the marl type of soil with respect to the hydrated lime.

The apparently coarse-grained and non-plastic in nature of the marl soil resulted in relatively reduced cementation with the lime addition, and hence causes considerable amount of loss in material engineering perspective.

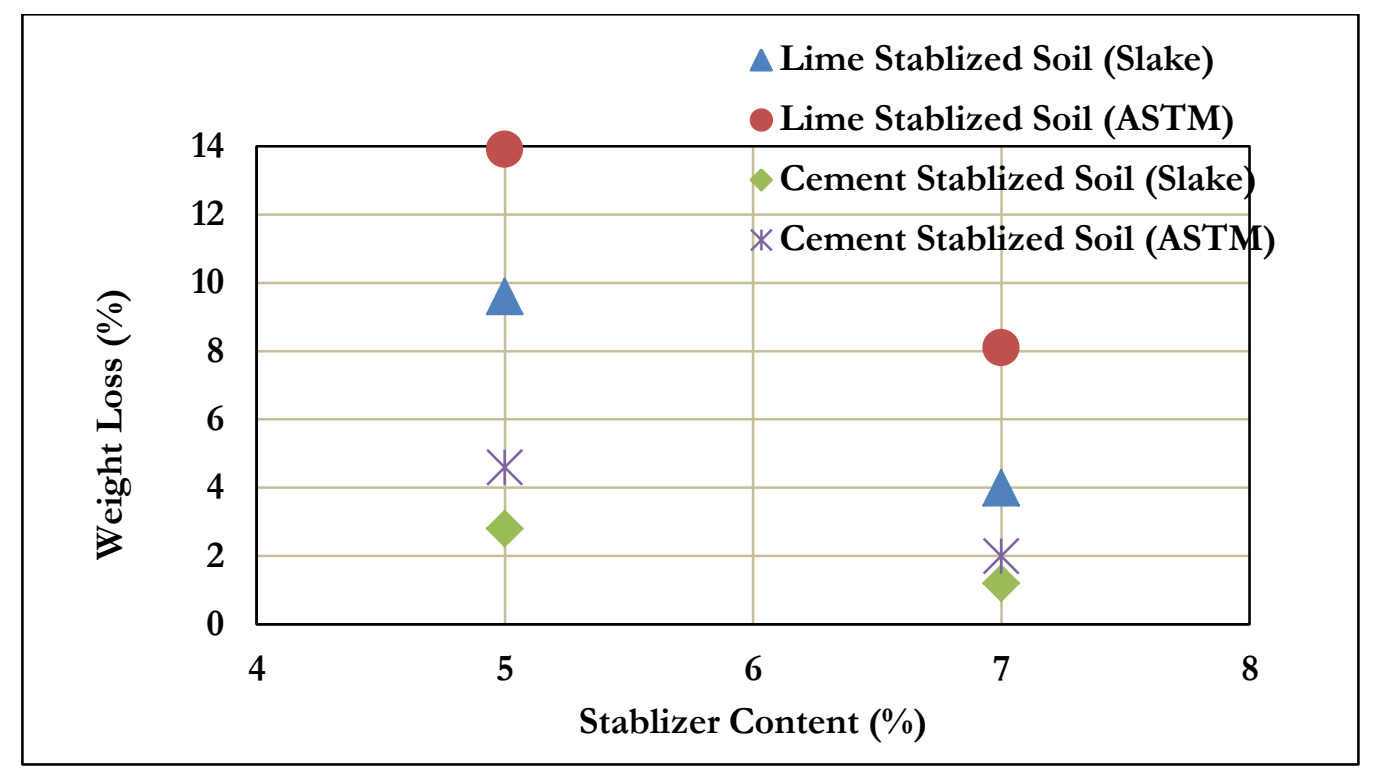

Fig. 2. Stabilizer content effect on the durability properties of stabilized marl soil specimens [2].

The durability criteria requirements were well satisfied by marl soil which are stabilized using the both $5 \%$ and $7 \%$ lime and PC. Nonetheless, stabilization with cement achieved better results, with the material losses found to be less than that for marl soil stabilized with lime.

\section{Summary and Conclusion}

In Eastern Saudi Arabia, marl is the most popular construction material which has wide variability in its constituents and properties. However, some problems which appear in constructed facilities do arise the need for improving this soil. Based on the analysis the following conclusions are drawn:

1. Portland cement (PC) is the most popular and cost effective stabilizing agent for Marl Soils in Saudi Arabia.

2. The results indicate that addition of a small percentage of Portland cement (as low as 3\% by the dry weight of soil) to Marl produces strong, water-resistant, and durable material. Cement is recommended to be added to the Marl in an increment of $2 \%$.

3. If liquid asphalt used for Marl stabilization, a small amount of Portland cement $(2 \%)$ is suggested to be used to improve the strength. 
4. The performance of Marl soils is excellent when it is compacted at its optimum moisture contents. However, little deviation from the optimum moisture content, even within the $95 \%$ density limits, may cause a complete collapse (strength loss) whereby the CBR value is reduced from 100 to less than 10.

5. Most of the results consider that the performance of Marl soil stabilized with cement is much superior to that stabilized using lime. Lime and cement stabilization satisfy the durability requirement with less material losses in cement.

No investigation have been carried out and found to improve Marl soils using Geo-synthetics application which can be recommended to protect it from moisture related adverse actions.

\section{Recommendations}

As most of the construction problems related to shallow foundations such as road bases, sub bases and building foundations in Eastern Saudi Arabia, are attributed to the sensitivity of construction materials to moisture, it is, therefore, recommended to use a low percentage of Portland cement (2-4\%) when used in a high water table environment or use strict quality control procedures where Marl should be compacted to at least $95 \%$ modified proctor at a moisture content close to the optimum value.

During the period from 1987 to 2016, a few studies were conducted to improve Marl in Saudi Arabia; therefore, it is recommended for the researchers to conduct more studies in this area due to its importance.

\section{Acknowledgement}

We would like to thank University of Bahrain (UOB) and KFUPM, Saudi Arabia for supporting the conducted research work. Specially, the graduate student research support is much appreciated.

\section{References}

[1] M. Arifuzzaman, M. A. Habib, M. K. Al-Turki, M. Khan, and M. Ali, "Improvement and characterization of sabkha soil of saudi arabia: A review," Jumal Teknologi, vol. 78, pp. 1-11, 2016.

[2] O. S. B. Al-Amoudi, K. Khan, and N. S. Al-Kahtani, "Stabilization of a Saudi calcareous marl soil," Construction and Building Materials, vol. 24, pp. 1848-1854, 2010.

[3] S. A. Aiban, "Strength and compressibility of Abqaiq marl, Saudi Arabia," Engineering Geology, vol. 39, pp. 203-215, 1995.

[4] A. B. M. S. Islam, M. Jameel, and M. Z. Jumaat, Boring, Sampling and Field Testing in Soil Investigation, First ed. Saarbrücken, Germany: VDM Publishing, 2011.

[5] S. M. Islam, R. Hashim, and A. B. M. S. Islam, "Behaviour of peat-added composite bricks in low-cost building construction," Materials Research Innovations, vol. 18, pp. 1-5, 2014.

[6] S. M. Islam, R. Hashim, A. B. M. S. Islam, and R. Kurnia, "Effect of peat on physicomechanical properties of cemented brick," The Scientific World Journal, vol. 2014, p. 8, 2014.

[7] N. K. Mishra and S. Rath, "Cost effectiveness of clayey soil \& moorum, treated with fly ash-lime for construction of low volume roads," International Journal of Civil and Structural Engineering, vol. 2, p. 370, 2011.

[8] S. Aiban, H. Al-Abdul Wahhab, and O. Al-Amoudi, "Identification, evaluation and improvement of eastern Saudi soils for constructional purposes," Final Report, KACST Project AR-14-61, 1999.

[9] S. A. Aiban, H. I. A.-A. Wahhab, O. S. B. Al-Amoudi, and H. R. Ahmed, "Performance of a stabilized marl base: a case study," Construction and Building Materials, vol. 12, pp. 329-340, 1998.

[10] O. N. Maaitah, "Evaluation of Al-Karak ash for stabilization of marl clayey soil," Electronic Journal of Geotechnical Engineering, vol. 17, 2012.

[11] M. Kavvadas, A. Anagnostopoulos, V. Georgiannou, and M. Bardanis, "Characterisation and engineering properties of the Corinth Marl," in Proceedings of International Workshop "Characterisation and Engineering Properties of Natural Soils', Singapore, 2002, pp. 1435-1459.

[12] S. A. Aiban, "A study of sand stabilization in eastern Saudi Arabia," Engineering Geology, vol. 38, pp. 6579, 1994. 
[13] S. A. Aiban, "Strength and leaching characteristics of abqaiq marl," in Fourth Saudi Engineering Conference Jeddah, 1995, pp. 393-399.

[14] H. A.-A. Wahhab and I. Asi, "Improvement of marl and dune sand for highway construction in arid areas," Building and environment, vol. 32, pp. 271-279, 1997.

[15] A. Qahwash, "Geotechnical properties of fine-grained calcareous sediments for engineering purposes," Engineering Geology, vol. 26, pp. 161-169, 1989.

[16] A. A. E. Aal and A. A. Al-Homidy, "Economic feasibility of using by-products in soil stabilization, Saudi Arabia," International Journal of Advanced Engineering Research and Science (IJAERS), vol. 3, pp. 58-78, 2016.

[17] A. El Howayek, M. Santagata, A. Bobet, and N. Zia-Siddiki, "Engineering properties of marls," FHWA/IN/JTRP-2015/11, West Lafayette, IN: Purdue University, 2015.

[18] F. Lamas, C. Irigaray, and J. Chacón, "Geotechnical characterization of carbonate marls for the construction of impermeable dam cores," Engineering geology, vol. 66, pp. 283-294, 2002.

[19] A. Koroljova and A. Pototski, "Use of oil shale fly ash as a binder material in stabilization of soft soils," in Proceedings of the 12th Internation Symposium on Tropical Problems in the Field of Electrical and Power Engineering, Kuressaare, Estonia, June, 2012, pp. 11-16.

[20] J. Kumpiene, A. Lagerkvist, and C. Maurice, "Stabilization of Pb-and Cu-contaminated soil using coal fly ash and peat," Environmental pollution, vol. 145, pp. 365-373, 2007.

[21] Y. Laor, M. Naor, U. Ravid, P. Fine, I. Halachmi, Y. Chen, and R. Baybikov, "Odorants and malodors associated with land application of biosolids stabilized with lime and coal fly ash," Journal of environmental quality, vol. 40, pp. 1405-1415, 2011.

[22] L. Lopes, P. Vargas, M. Casagrande, and L. Motta, "Availability of resilient modulus and permanent deformation laboratory tests of stabilized soil with coal ashes for pavements base," in Key Engineering Materials, 2012, pp. 570-576.

[23] K. M. Rao and G. R. Subbarao, "Optimum fly ash for mechanical stabilization of expansive soils using 22 factorial experimental design," Natural hazards, vol. 60, pp. 703-713, 2012.

[24] E. O. Tastan, T. B. Edil, C. H. Benson, and A. H. Aydilek, "Stabilization of organic soils with fly ash," Journal of geotechnical and Geoenvironmental Engineering, vol. 137, pp. 819-833, 2011.

[25] K. Yang and Z. Tang, "Effectiveness of fly ash and polyacrylamide as a sand-fixing agent for wind erosion control," Water, Air, \& Soil Pollution, vol. 223, pp. 4065-4074, 2012.

[26] M. H. Al-Malack, G. M. Abdullah, O. S. B. Al-Amoudi, and A. A. Bukhari, "Stabilization of indigenous Saudi Arabian soils using fuel oil flyash," Journal of King Saud University-Engineering Sciences, vol. 28, pp. 165-173, 2016.

[27] H. I. A.-A. Wahhab, M. G. Baig, I. A. Mahmoud, and H. M. Kattan, "Study of road bases construction in Saudi Arabia using foam asphalt," Construction and Building Materials, vol. 26, pp. 113 $121,2012$.

[28] G. M. Abdullah and H. I. A.-A. Wahhab, "Evaluation of foamed sulfur asphalt stabilized soils for road applications," Construction and Building Materials, vol. 88, pp. 149-158, 2015. 